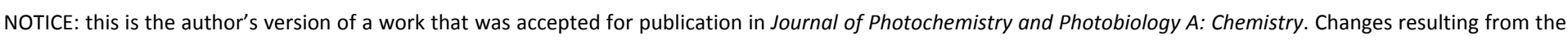

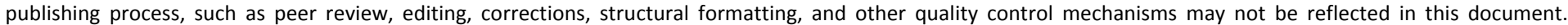

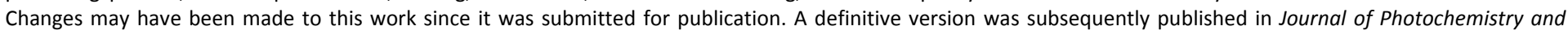
Photobiology A: Chemistry [Vol. 290, p. 45-43, September 2014]. DOI: 10.1016/j.jphotochem.2014.05.016

3

4

5

6

7

8

\title{
Elucidating bacterial regrowth: Effect of disinfection conditions in dark storage of solar treated secondary effluent
}

\section{Stefanos Giannakis ${ }^{1,2,3}$, Efthymios Darakas ${ }^{1}$ Antoni Escalas-Cañellas ${ }^{2,4}$, César Pulgarin ${ }^{3, *}$}

${ }^{1}$ Laboratory of Environmental Engineering and Planning, Department of Civil Engineering, Aristotle University of Thessaloniki, 54624 Thessaloniki, Greece

${ }^{2}$ Laboratory of Control of Environmental Contamination, Institute of Textile Research and Industrial Cooperation of Terrassa (INTEXTER), Universitat Politècnica de Catalunya, Colom 15, 08222 Terrassa, Catalonia, Spain

${ }^{3}$ Swiss Federal Institute of Technology, Lausanne, Institute of Chemical Sciences and Engineering, 1015 Lausanne, Switzerland

${ }^{4}$ Department of Chemical Engineering \& Terrassa School of Engineering, Universitat Politècnica de Catalunya, Colom 1, 08222, Terrassa, Catalonia, Spain

*Corresponding author: César Pulgarin, Tel: +41216934720; Fax: +41216936161 E-mail: cesar.pulgarin@epfl.ch

\section{Abstract}

In this study, we systematically investigate solar disinfection of synthetic secondary wastewater, with the effort to decrypt the effects disinfection conditions have on post-irradiation bacterial regrowth in the dark. A full factorial design of 240 experiments was employed to investigate the effects of i) exposure time $(1,2,3$ and $4 \mathrm{~h})$, ii) treatment temperature $\left(20,30,40,50\right.$ and $\left.60^{\circ} \mathrm{C}\right)$, iii) initial bacterial concentration $\left(10^{3}, 10^{4}, 10^{5}\right.$ and $\left.10^{6} \mathrm{CFU} / \mathrm{mL}\right)$ and iv) sunlight intensity $\left(0,800\right.$ and $\left.1200 \mathrm{~W} / \mathrm{m}^{2}\right)$ on Escherichia coli survival for a subsequent 48 -h dark control period. The decisive implications treatment temperature inflicted in regrowth were monitored and interpreted within two temperature ranges, from $20-40^{\circ} \mathrm{C}$ and $40-60^{\circ} \mathrm{C}$. In dark tests, bacterial populations presented initial moderate growths at $20-40^{\circ} \mathrm{C}$ range, followed by intense regrowth. At $40-60^{\circ} \mathrm{C}$ range, acute thermal inactivation without long-term regrowth predominated at $50^{\circ} \mathrm{C}$ and was total at $60^{\circ} \mathrm{C}$, within the 4 -h treatment period. Introduction of light resulted in higher removal rates or permanent inactivation for $800 \mathrm{and} /$ or $1200 \mathrm{~W} / \mathrm{m}^{2}$, respectively. No post-treatment regrowth in the dark was observed after 24 and $48 \mathrm{~h}$, in completely inactivated samples, and its demonstration, when observed, was well correlated to the bacterial numbers at the end of the disinfection period. Statistical observations on the transferred bacterial populations from day to day are also discussed in this paper.

Keywords: Solar disinfection, wastewater, full factorial design, E. coli, regrowth, dark repair 


\section{Research Highlights}

38

- 240 solar disinfection experiments were performed, focusing on regrowth

- The effects treatment conditions on bacterial dark repair were evaluated.

- No regrowth was observed in samples with null counts.

- Regrowth was more intense in low-temperature treatment.

- The live fraction at the end of treatment influences short and long-term regrowth.

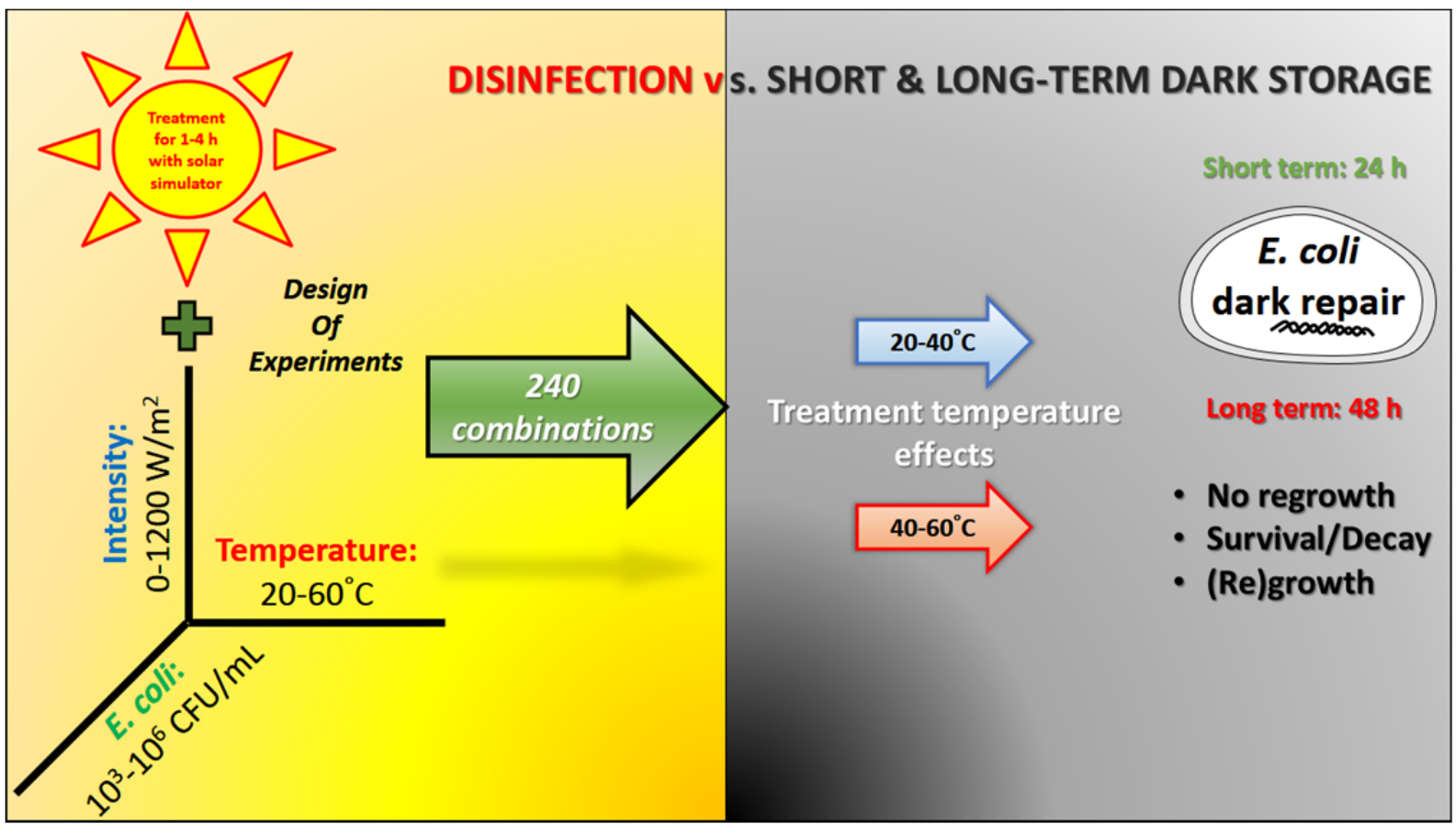




\section{INTRODUCTION}

The greatest disadvantage of UV disinfection of wastewater, regardless of the source, i.e. either mechanical (UV-C lamps) or physically induced (solar UV disinfection), is its point efficiency, which lacks residual effect (White, 2010). In any UV disinfection unit, the effluent of the process will include inactive (completely decayed microorganisms), injured (not lethally damaged, potentially dangerous if healed) and a fraction of microorganisms that escaped the process. The absence of the residual disinfecting factor could possibly allow the reactivation of injured microorganisms, if favorable downstream conditions are presented (Hijnen et al., 2006; Hallmilch and Gehr, 2010). The remaining bacteria could increase their numbers while being in the treated effluent, due to a variety of reasons; for example, the existence of nutrients and related chemicals in wastewater could provide an abundant food source for the bacteria, allowing them to metabolize and reproduce (Marugan et al, 2010). Hence, the main two factors that are responsible for bacterial regrowth are (Guo et al, 2011): i) the growth of injured microorganisms ii) the reactivation and regrowth of the reactivated microorganisms.

Long after regrowth as a phenomenon was observed, the "viable but non-cultivable" (VNC) hypothesis was developed to explain the repopulation of a sample, although appearing microorganismfree at the end of the treatment; this statement provided explanations to similar findings and was adopted by various researchers (Xu et al, 1982; Roszak and Colwell, 1987). This hypothesis suggests that not all the bacteria are destroyed by the action of light, but there is a significant number that is alive, but unable to reproduce.

DNA is one of the main targets of both direct and indirect actions of UV light, through the direct dimerization of thymines or indirect attacks by reactive oxygen species, (ROS) (Pigeot-Remy et al., 2012). The generated ROS have a well-explained action mode, especially hydroxyl radicals; they interact with the intracellular components of the microorganism. Bacteria possess the ability to repair a number of their DNA damages through two main mechanisms: light-dependent ones, namely photoreactivation, and light-independent (dark repair), which help them recover from during photoexposure.

Photoreactivation is completed by a two-step mechanism. First, there is the formation of a complex between a photoreactivation enzyme (PRE) and the dimer to be repaired (Nebot Sanz et al, 2007) and afterwards, release of PRE and repaired DNA. The restoration of the dimer to its original monomerized form is absolutely dependent upon light energy intensity (Nebot Sanz et al, 2007); the energy needed to repair the damage is provided by visible light $(310-480 \mathrm{~nm}$ ) (Hijnen et al, 2006; Guo et al, 2011).

The dark repair methods are regulated by the expression of recA, a critical gene in the bacterial cell, with well-known properties (Sinha and Hader, 2002; Jungfer et al., 2007). The nucleotide and base 
excision repair, includes numerous molecular steps, including identification of the damage, assimilation of a repair complex, incision and removal of the damaged strand and filling with DNA polymerase, finalized by attaching the replaced DNA with the rest of the strand with a ligase (Britt, 1996; Amsler, 2008; Shang et al, 2009).

There is extensive literature on the genetic interpretation of regrowth, as well as experimental findings on the factors that affect this process; among the most common factors affecting regrowth are the effects of temperature (Chan and Killick, 1995; Shang et al., 2009), the salt and nutrient contents of the treated water (Munshi et al., 1991; Rincon and Pulgarin 2004a), the effect of UV dosage and light intensities (Lindenauer and Darby, 1994; Nebot Sanz et al., 2007), the pre-illumination with noncoherent visible and infrared wavelengths (Lage et al., 2000), the initial bacterial population (Craik et al., 2001; Gomes et al., 2009b) and the type of bacterial strain (Rincon and Pulgarin, 2004b). However, most of the works either focus on photoreactivation, employ artificial UVC irradiation, focus on drinking water or treat regrowth exclusively as added value on the evaluation of a treatment method. This occurs due to the fact that dark repair tests offer a good evaluation of the durability of a process, namely the ability to handle post-treatment events.

The present study focuses clearly on bacterial dark repair of previously solar irradiated of secondary effluent. After the extensive works for drinking water in developing regions (Wegelin et al., 1994; McGuigan et al., 1998; Martin-Dominguez, 2005), there is an interest in introducing low-cost treatment methods in developing countries, in order to efficiently help controlling contagious diseases (McGuigan et al., 2012); solar disinfection of wastewater could offer a solution, under certain conditions. A system that could treat the effluent, for instance a series of shallow ponds, and could drastically reduce microbial load, would be of great interest in these areas, where the number of sunny days per year is an order of hundreds (Meichtry et al., 2005). In that manner, there would be an extra source of water, maybe not for direct consumption, but potentially able to enrich local availability, intended for secondary use (Gamage and Zhang, 2010). Such a practice would be of equal interest in both developed and developing countries, since a considerable amount of water could be recovered.

Considering the application point of view, a preliminary approach has been done (Giannakis et al. 2014), in terms of complexity of factors involved, but there are few statistical findings and experimental processes verifying the effect of basic parameters of treatment, for instance, treatment time (Polo-Lopez et al. 2011) and temperature conditions with regard to the dark repair potential of the target bacterial population. Bacterial regrowth has been observed to occur in water samples (Rincon and Pulgarin, 2004b; Sciacca et al., 2010). Wastewater is a rich in nutrients matrix which could support bacterial growth, and given the time treated water could spend in the dark, due to the storage times potentially required to further use reclaimed water, regrowth is rendered as a primary problem in water disposal in natural water bodies or the reuse.

Therefore, in this study we recreate the conditions of solar treatment of secondary effluent and perform a multilevel, full factorial design of experiments (DOE), in order to fully investigate the 
122 effects of the treatment conditions, during solar disinfection, on bacterial regrowth. With the 123 application of an experimental design valuable information can be acquired that are not evident due to 124 interaction of the parameters (Montgomery, 2001); the factorial experimental design has been proven 125 an efficient method in bacterial inactivation studies (Rodriguez-Chueca et al., 2012; Giannakis et al., 126 2014). The parameters under investigation are i) exposure time, ii) temperature, iii) initial population 127 and iv) intensity of the solar simulated light, on E. coli-spiked synthetic wastewater, as a model 128 microorganism. After the measurements of the process efficiency, post-treatment control in the dark 129 was made, to estimate the bacterial regrowth/survival capabilities of the treated samples. 


\subsection{Preparation of the synthetic secondary effluent}

The pre-experimental processes involved with the preparation of the synthetic wastewater included

\subsubsection{Bacterial culture preparation}

E. coli K12 (MG 1655) was acquired from "Deutsche Sammlung von Mikroorganismen und Zellkulturen". A colony was loop-inoculated in pre-sterilized $5 \mathrm{~mL}$ Luria-Bertani broth; for each $\mathrm{L}$ of sterile distilled water, $10 \mathrm{~g} \mathrm{Bacto}^{\mathrm{TM}}$ Tryptone, $5 \mathrm{~g}$ Yeast extract and $10 \mathrm{~g} \mathrm{NaCl}$ were added. $25 \mathrm{~mL}$ sterile plastic falcons, containing the spiked LB, were incubated for $8 \mathrm{~h}$ and another 1/100 dilution to LB solution (2.5 mL sample into $250 \mathrm{~mL} \mathrm{LB})$ was incubated for another $15 \mathrm{~h}$. Bacterial cells were then centrifuged (5000 rpm for $15 \mathrm{~min}$ ) and washed 3 times with sterilized saline solution $(8 \mathrm{~g} / \mathrm{L} \mathrm{NaCl}$ and $0.8 \mathrm{~g} / \mathrm{L} \mathrm{KCl}$ ). The bacterial pellet was dispersed in fresh, sterilized saline solution, forming a solution with $10^{9} \mathrm{CFU} / \mathrm{mL}$ initial population.

\subsubsection{Synthetic wastewater composition}

The employed wastewater was a 1/10 dilution of the presented in Table 1, instructed by OECD (1999). $1 \mathrm{~mL}$ of the prepared $\left(10^{9}\right)$ bacterial solution was added per liter to obtain a bacterial concentration of $10^{6} \mathrm{CFU} / \mathrm{mL}$. In order to obtain $10^{3}, 10^{4}$ and $10^{5} \mathrm{CFU} / \mathrm{mL}$, dilution of the same proportion (wastewater/distilled water $=1 / 10)$ were done.

\subsection{Suntest solar simulator}

The artificial solar simulator employed in our experiments employed was a Suntest, acquired from Hanau. It bears a $1500 \mathrm{~W}$ air-cooled Xenon lamp, and provides $560 \mathrm{~cm}^{2}$ effective illumination surface. $0.5 \%$ of the emitted photons belong to the UVB area and 7\% in UVA. Cut-off filter ensures no UVC is emitted and IR as well. The spectrum above $400 \mathrm{~nm}$ follows the natural solar one. The intensity levels were measured by a Kipp \& Zonen Mod. CM3 and CUV3 radiometer. 


\subsection{Batch reactors}

164

165

166

167

168

169

170

171

172

173

174

175

176

177

178

179

180

181

182

183

184

185

186

187

188

189

190

191

192

All tests were performed in cylindrical glass reactors, with double walls that allow recirculation of thermostated water, for temperature control. The effective irradiation surface was $20.41 \mathrm{~cm}^{2}$. Also, mild stirring took place during all the experiments with a magnetic stirrer; sampling was always done while stirring, from the body of the sample.

\subsection{Sampling and post-experimental handling of samples}

Sampling was performed in hourly manner and irradiated microorganisms were kept in plastic vials in the dark, covered by aluminum foil, in room temperature $\left(20^{\circ} \mathrm{C}\right)$. Regrowth tests were conducted exactly after 24 and 48 hours from the sampling time. An important point is that the samples were kept in sterile vials for the said period to avoid enhanced bacterial regrowth (Sciacca et al., 2010).

\subsection{Bacterial enumeration}

Viable bacterial counts after solar treatment were assessed by pour-plating on non-selective agar as suggested by Reed (2004) and Rizzo (2004), in order to obtain all viable counts, after proper dilution in sterile saline solution to achieve measurable counts on the dishes (15-150 colonies). Experiments were performed with duplicate plating in three consecutive dilutions. Difference was less than $5 \%$ and maximum $10 \%$ in undiluted samples, therefore, error bars will be omitted for reasons of clarity, only the average counts.

\subsection{Experimental design set-up}

A multilevel, full factorial DOE was employed to assess the influence of i) treatment time, ii) temperature, iii) initial bacterial population and iv) light intensity. The full factorial design allows measuring the response (i.e. disinfection and/or regrowth after 24 and $48 \mathrm{~h}$ ) in all different levels and combinations (Rodriguez-Chueca et al., 2012). MINITAB for Windows was used to analyze the data. Table 2 summarizes the selected parameters, as well as their respective levels of study. 


\subsection{Disinfection Experiments}

Figure 1 summarizes the results obtained through the DOE focused on the study of treatment time, temperature during treatment and initial bacterial population. Their effects on disinfection efficiency, are grouped by the three intensity levels, for clarity. A detailed study on the antagonistic and synergistic effects of temperature was previously performed (Giannakis et al., 2014), whose summary is presented here. Figure 1 a summarizes the results in absence of light, $1 \mathrm{~b}$ the $800-\mathrm{W} / \mathrm{m}^{2}$ results and $1 \mathrm{c}$ the $1200-\mathrm{W} / \mathrm{m}^{2}$ ones, respectively. The accompanying Table 3 is also grouped in three distinct areas, according to the applied irradiation intensity and presents the percentage of removal only at the end of the 4-h period of treatment, excluding the cases of $0 \mathrm{~W} / \mathrm{m}^{2}$, temperatures 20,30 and $40^{\circ} \mathrm{C}$; removal rate was always 0 and growth rates are presented instead.

From Figure 1a and Table 3, we draw the information that when no irradiation is applied the disinfection process is temperature-driven. However, E. coli are mesophilic microorganisms that demonstrate their maximum growth in the most comfortable temperature for them, around $37^{\circ} \mathrm{C}$ (Fotadar et al., 2005). Therefore, taking into account the favorable existence of nutrients and salts in the system (Marugan et al., 2010) a different (increasing) growth rate for each temperature range is observed, until $40^{\circ} \mathrm{C}$, when it reaches its peak. After this point, at $50^{\circ} \mathrm{C}$ and even more at $60^{\circ} \mathrm{C}$, thermal inactivation dominated the outcome of the experiment, near-total and total inactivation after 4h of exposure to heat. This is somewhat expected, since the thermal stress applied to the cells is denaturizing proteins and alters cell membrane significantly, up to a fatal point (Blaustein, 2013). For the study of both disinfection and regrowth, this will be considered as a boundary condition and all cases will be studied separately.

When light is applied to the system, there is an extra stress inflicted on the system. The solar simulator emits photons within the UVB, UVA and visible light region. Literature suggests the mode of action of light against bacteria, summarized in direct DNA strand damage (Hallmilch and Gehr, 2010; Matalana-Surget, 2012) and indirect damage through reactive oxygen species (ROS) production (Regensburger et al., 2011), due to UVB light. UVA damages the cells indirectly, also through ROS generation inside and outside the cell (Spuhler et al., 2010; Pigeot-Remy et al., 2012). Also, synergy between light and temperature is reported (McGuigan et al., 1998; Rincon and Pulgarin, 2004c), which enhances the disinfecting action.

This is also observed in our case, where we notice elevated removal rates when $800 \mathrm{~W} / \mathrm{m}^{2}$ irradiance was applied, for all temperature levels, although higher for the higher temperatures (Figure 1b, Table 3). Normally, the maximum irradiance value reaching Earth's outer layers of atmosphere is 1360 $\mathrm{W} / \mathrm{m}^{2}$ and around the equator, the normal values fluctuate around $1120 \mathrm{~W} / \mathrm{m}^{2}$ (McGuigan et al., 2012). 
However, in low temperatures, the growth rate is disrupting the expected inactivation behavior, with this mitigation effect increasing towards $40^{\circ} \mathrm{C}$. This intensity level was proven enough to control excess growth, but did not provide proper disinfection in this timeframe. However, when $1200 \mathrm{~W} / \mathrm{m}^{2}$ were inflicted, the balance between the growth and the inactivation coming from the light actions has turned to the disinfection side, demonstrating total inactivation in $4 \mathrm{~h}$ for all temperatures and initial population levels. The synergy between light and temperature is reflected in disinfection times, where $4 \mathrm{~h}$ were required for low temperatures, a little less for $50^{\circ} \mathrm{C}$ and $0.5 \mathrm{~h}$ for $60^{\circ} \mathrm{C}$ (Figure 1c, Table 3).

\subsection{Parameters affecting survival and regrowth after $0 \mathrm{~W} / \mathrm{m}^{2}$ irradiation experiments}

As far as the post-treatment events are concerned, we divide the behavior of E. coli into two groups: treated under mild temperatures $\left(20-40^{\circ} \mathrm{C}\right)$ or treated in higher temperatures than $40^{\circ} \mathrm{C}$. The first group of graphs presenting the experiments performed in lower temperatures (Figure 2a), demonstrates a high increase of the bacterial population, influenced by the pre-treatment conditions. It is clear that the samples treated at $40^{\circ} \mathrm{C}$, present higher dynamics of growth and relatively higher final counts after 24 and $48 \mathrm{~h}$. Also, there is visible influence of the initial population, by which higher initial populations result in higher reproduction rates after $48 \mathrm{~h}$. In addition, we can notice a gradual decrease in growth rates between the $1^{\text {st }}$ and the $2^{\text {nd }}$ day of storage, probably interpreted by the stress caused by some initial nutrient shortage, due to the overgrown bacterial numbers.

Figures $2 \mathrm{~b}$ and $2 \mathrm{c}$ are the contour plots that visualize all regrowth tests, performed by hourly sampling in all temperatures and initial population rates. They reveal that there is a correlation between the treatment temperature and the regrowth after 24 or $48 \mathrm{~h}$ (expressed by $\mathrm{C}_{24} / \mathrm{C}_{0}$ and $\mathrm{C}_{48} / \mathrm{C}_{0}$ ). These fractions reveal the regrowth of the bacterial numbers higher than the initial one; if the ratio is $<1$, then we observe survival, instead. Lower temperatures present suppressed rates, compared to higher ones. Also, we notice the difference between the bacterial number after $24 \mathrm{~h}$ and $48 \mathrm{~h}$, being influenced by the disinfection conditions, which is expressed in orders of magnitude. Plus, temperatures that initially seemed safer against regrowth (around $25^{\circ} \mathrm{C}$ ), demonstrate equally high rates. In figures $2 \mathrm{~d}$ and $2 \mathrm{e}$, the correlation between treatment time and regrowth is presented; the prolongation of the experiment has a profound effect in the bacterial numbers observed after 2 days. However, initial concentration cannot be attributed to a direct effect. In the last sub-graphs which present the main effects of the temperature on regrowth, elevating temperature during treatment is observed to have a strong and rather linear impact only over $30^{\circ} \mathrm{C}$ for the regrowth after one day, and stronger for after two days.

The samples treated under higher temperatures (Figure 3a) do not present any recovery of the population; the population, if any bacteria still existed, continued the decay during dark storage. For the bacterial samples treated at $50^{\circ} \mathrm{C}$, although total inactivation was not observed, after $24 \mathrm{~h}$ no viable counts were observed. As it seems, the thermal damage rendered bacteria unable to reproduce; no 
repair mechanism was observed to act. The remaining samples, after their treatment at $60^{\circ} \mathrm{C}$, presented the same behavior. Higher temperatures accelerated inactivation, which was total within the 4-h timespan, and no regrowth was observed thereafter.

Contour plots $3 \mathrm{~b}$ and $3 \mathrm{c}$, present the survival rates after 24 and 48 hours, for all hourly samples taken during disinfection. First of all, high regrowth risk $\left(\mathrm{C}_{24} / \mathrm{C}_{0}\right.$ and $\left.\mathrm{C}_{48} / \mathrm{C}_{0} \geq 1\right)$ is observed around $50^{\circ} \mathrm{C}$ and for 60-90 min of treatment. The survival pattern for the rest of temperatures and time is consistent, for the two post-treatment days, and slightly more elevated numbers are observed after 2 days. The main effects plots (figures $3 \mathrm{~d}$ and $3 \mathrm{e}$ ) demonstrate the inverse effect that high-temperature treatment has on regrowth; as time passes, survival capability is diminishing, and as temperature increases, we observe the same effect. However, initial population follows a similar pattern from the first to the second day.

\subsection{Effects of $800 \mathrm{~W} / \mathrm{m}^{2}$ irradiance on the parameters affecting survival and regrowth}

Figures 4 and 5 present the extension of monitoring the bacterial population for 48 more hours after $800-\mathrm{W} / \mathrm{m}^{2}$ intensity irradiation is complete. Results are grouped per temperature range $\left(20-40^{\circ} \mathrm{C}\right.$ and $50-60^{\circ} \mathrm{C}$ ) and initial concentration of bacteria. It can be deduced that post-irradiation survival is more complex, compared to the experiments in absence of light.

The first temperature range $\left(20-40^{\circ} \mathrm{C}\right.$, Figure 4$)$ demonstrates very low inactivation rates, and as a consequence, presents elevated (re)growth/survival rates; since there is no total inactivation taking place (i.e. zero viable counts), the recovery of the bacterial numbers could be attributed to i) alive bacteria that continued replicating, ii) bacteria that recovered their DNA lesions by dark repair methods, and growth of the revived bacteria (Guo et al., 2011).

The contour plots (Figure $4 \mathrm{~b}$ and $4 \mathrm{c}$ ) demonstrating the bacterial population after 24 or $48 \mathrm{~h}$, reveal an interesting behavior, as far as the influence temperature is concerned. Although $40^{\circ} \mathrm{C}$ is a breaking point, where bacterial disinfection is drastically changing, it appears that $30^{\circ} \mathrm{C}$ is the most critical value for regrowth. First of all, after $24 \mathrm{~h}$, regrowth is not probable, and only occurred from samples treated around $3-4 \mathrm{~h}$ and $30-40^{\circ} \mathrm{C}$. On the contrary, samples that were treated in low temperatures and for short time, present low counts after $24 \mathrm{~h}$.

Normally, bacteria in samples that remain for longer time under illumination tend to get more inactivated, as it is shown in figure 4a. However, prolonging their treatment in this favorable temperature promotes multiplication and therefore, new strains, that gain resistance against solar irradiation in conditions of exposure to (visible) light (Hijnen et al, 2006; Nebot Sanz et al, 2007; Shang et al, 2009). This bacterial ability is a heritage of evolution through time, to protect themselves from the natural ultraviolet rays from the sun (Quek and $\mathrm{Hu}, 2008$ ). 
As a consequence, higher remaining populations led to higher survival rates from the bacteria. Although Lindenauer and Darby (1994) supported that no significant correlation exists between regrowth and the initial number of coliforms in wastewater, at any dose, they found out that in low doses, the surviving coliforms affected the reactivation rates. Craik et al (2001) explained this noting that if the initial population is high, there is a big chance that there will be a part of it going through unharmed due to shielding (by each other) and bad mixing.

After $48 \mathrm{~h}$, we notice a change in the effect; in figure 1c, we observe that samples treated in lower temperatures and for shorter times, demonstrate higher regrowth rates and samples that presented regrowth show 5-fold suppressed rates, instead. This is clearly demonstrated in the main effects plot, where treatment times reveal inverse action, and $30^{\circ} \mathrm{C}$ reveal their statistical significance in regrowth. This can be explained, mostly by the action of light; samples that were treated for a short time accumulated a relatively low dose, and were able to recover their cultivability, whereas samples that were treated in high temperatures (and showed high regrowth), remained for a long time under illumination, and their repair capabilities were diminished.

The behavior of bacteria that were treated in high temperatures is more straightforward. First of all, almost no regrowth is observed; all values for $\mathrm{C}_{24} / \mathrm{C}_{0}$ and $\mathrm{C}_{48} / \mathrm{C}_{0}$ are $<1$. Hence, we can deduce that it is crucial to obtain null bacterial counts at the end of the experiments (total inactivation) in order to avoid their re-appearance. The combined action of light and temperature, and the joint actions are proven to be not only more efficient (faster), but hinder re-population as well. Among the figures $5 \mathrm{~b}$ and 5c, that picture bacterial survival after 24 and 48 hours, the highest survival rates have appeared around 1.5-2 h, but are still low ones. This peak is explained by the influence of the type of concurring actions in the batch tests employed in this study: we mentioned that there is an equilibrium of growth and inactivation, and it appears to bend, in favor of inactivation, at this time point, for $50^{\circ} \mathrm{C}$. Beyond this time mark, inactivation is higher, and as inactivation negatively influences regrowth, lower rates are observed. Finally, in the main effects plot in figures $5 \mathrm{~d}$ and $5 \mathrm{e}$, temperature and time have a straightforward effect, where prolongation of treatment equals to regrowth suppression; this is considered normal, since higher experimental times assists both bacterial protein damage and light inactivation.

\subsection{Effects of $1200 \mathrm{~W} / \mathrm{m}^{2}$ irradiance on the parameters affecting survival and regrowth}

In Table 3, the total inactivation achieved after $4 \mathrm{~h}$ in all samples has been demonstrated, in all temperature ranges and initial population, at $1200 \mathrm{~W} / \mathrm{m}^{2}$. As it seems, apart from the contribution of temperature we have verified the beneficial effect for switching from thermal to light/thermal treatment, now it is evident that light has a significant, additional role in bacterial inactivation (Ubomba-Jaswa et al., 2009); for the same temperature levels and initial bacterial population in the 
samples, the outcome was altered, when intensity was increased from 800 to $1200 \mathrm{~W} / \mathrm{m}^{2}$. The synergy of light and temperature has reached the maximum inactivating action (among our cases), leading to null bacterial counts, at the end of the treatment, for another 2 days. role in regrowth appearance. against inactivation, but high intensities overcome this effect. bacteria have lost their ability to perform dark repair of their damage.

When moderate light $\left(800 \mathrm{~W} / \mathrm{m}^{2}\right)$ was applied and the conditions favored disinfection (all cases of $60^{\circ} \mathrm{C}$ treatment and $10^{3}-10^{4}$ at $50^{\circ} \mathrm{C}$ ), no regrowth was observed. Common denominator in all cases was a null bacterial count active at the end of the process. Therefore, it is expected that no regrowth will be observed. Figure 6 a demonstrates the post-treatment phenomena, after the illumination of the varied population samples subjected to the different process temperatures.

In the previous cases, only the outcome after the end of the treatment is plotted, for clarity. However, the contour plots of $\mathrm{C}_{24} / \mathrm{C}_{0}$ and $\mathrm{C}_{48} / \mathrm{C}_{0}$ (figures $6 \mathrm{a}, 6 \mathrm{~b}$ and $7 \mathrm{a}, 7 \mathrm{~b}$ ) contain information, for the fate of the microbial population at each hour and level of population and temperature. We observe that there are only two combinations that led to regrowth, deriving from samples that were irradiated for only 1 h, between 20 and $40^{\circ} \mathrm{C}$ and of high risk are the next $30 \mathrm{~min}$ for all temperatures. In this case, there is shortage of dose accumulation from the cells, so the reactivation is highly probable. This is reflected in the regrowth rates in day 2 , with the excess growth effects around $40^{\circ} \mathrm{C}$ playing the most important

The effect of time, demonstrated in the main effects plots (figures $6 \mathrm{c}$ and $6 \mathrm{~d}$ ) is in favor of bacterial inactivation; firstly, prolonging the samples in such high intensities renders bacteria unable to recover or deploy defense mechanisms, because the incoming photonic rate is very high to cope with, and secondly, we observe that after $2 \mathrm{~h}$ of treatment, $\mathrm{C}_{24} / \mathrm{C}_{0}$ and $\mathrm{C}_{48} / \mathrm{C}_{0}$ are less than 1 , and therefore, no regrowth is observed. Finally, temperature produces the same obstacles stated in the previous section,

The most effective combination, of high intensity and elevated temperatures, is demonstrated in figure 7, and shows a very low survival potential and also, for the first time, it is decreasing from day to day. The surviving populations are very low in and in condition unable to recover neither their numbers nor their cultivability and decay day by day. The main effects plots (figures $7 \mathrm{c}$ and $7 \mathrm{~d}$ ) demonstrate the negligible differences time and temperature have in survival. However, both main effects plot between $20^{\circ} \mathrm{C}-40^{\circ} \mathrm{C}$ and $40^{\circ} \mathrm{C}-60^{\circ} \mathrm{C}$ allow a good comparison on the effect of light intensity, if compared with the respective ones of $800 \mathrm{~W} / \mathrm{m}^{2}$ and $0 \mathrm{~W} / \mathrm{m}^{2}$. It is clear that although temperature has a strong effect, it affects (re)growth indirectly, through cell growth effects and thermal inactivation. Temperature on the other hand shows that it is the main active force leading to suppressed risk of bacterial reappearance. For $800 \mathrm{~W} / \mathrm{m}^{2}$, repair was possible, whereas for $1200 \mathrm{~W} / \mathrm{m}^{2}$, even after $1-2 \mathrm{~h}$ of exposure, 
Our study has employed direct plating to measure cultivable bacteria, therefore regrown or surviving

372

373

374

375

376

377

378

379

380

381

382

383

384

385

386

387

388

389

390

391

392

393

394

395

396

397

398

399

400

401

402

403

404

405

406

407

bacteria are treated as one, cultivable entity. Also, we have rather avoided suggesting an influence of the initial bacterial population, because of the lack of a straightforward correlation or tendency. Each population level withholds its own special effect; for instance, initial population of $10^{3}$ bacteria encounter more available nutrients per cell and initial population $10^{6}$ offer higher chances of aggregation and shielding; in both cases, surviving bacteria are offered an enhanced possibility of (re)growth. Therefore, in order to be able to correlate the influence of starting bacterial population in the regrowth period, some statistical indicators were used. A main target was to homogenize results, regardless of initial population, to aid the overall robustness of the treatment.

Figures $8 \mathrm{a}$ and $8 \mathrm{~b}$ demonstrate the correlation between the efficiency of the disinfection process, for all possible treatment times ( 1 to $4 \mathrm{~h}$ ) and the consequent regrowth, for samples that have been treated in low $\left(20^{\circ} \mathrm{C} \leq \mathrm{T} \leq 40^{\circ} \mathrm{C}\right)$ or high temperatures $\left(40^{\circ} \mathrm{C}<\mathrm{T} \leq 60^{\circ} \mathrm{C}\right)$. The $\Delta$ traces reveal the population after $24 \mathrm{~h}$ while the $\Delta$ traces, after $48 \mathrm{~h}$, expressed as the fraction of bacteria/initial population, for homogenization of the $20^{\circ} \mathrm{C} \leq \mathrm{T} \leq 40^{\circ} \mathrm{C}$ results, regardless of initial bacterial numbers. We observe that in overall, the population after $48 \mathrm{~h}$ is tending to be higher than the population after $24 \mathrm{~h}$. It also appears that as efficiency increases, the samples without regrowth are increasing (line indicating $\mathrm{C}_{24,48} / \mathrm{C}_{0}$ ratio=1), and a tendency to reduce their regrowth potential, according to the percentage of efficiency increase. However, for higher temperatures, we notice the significant absence of regrowth after $24 \mathrm{~h}$ (trace: $\$$ ) (line indicating $\mathrm{C}_{24,48} / \mathrm{C}_{0}$ ratio=1) and the suppression of growth after $48 \mathrm{~h}$ (trace: ${ }^{-}$), compared to the lower temperatures. Hence, treating in higher temperatures is detrimental in both short and long-term storage of the treated samples.

Furthermore, we calculated the alive (cultivable) number of bacteria left at the end of the process, and plotted with the population after 24 and $48 \mathrm{~h}$, for both low (figure 8c) and high temperatures of pretreatment (figure $8 \mathrm{~d}$ ). Figure $8 \mathrm{c}$ demonstrates a constant live bacteria/initial population ratio fluctuating around 1 after $24 \mathrm{~h}$ of treatment (trace: $\bullet$ ), but the bacterial numbers after 48 days (trace: $\bullet$ ) seem to decrease, as the live fraction increases; lower populations would be expected when the live fraction is lower. This indicates that the correlation between the pre-treatment and regrowth is not limited to the live fraction at the end of the given treatment time ( 1 to $4 \mathrm{~h}$ ), but is linked to the treatment method. For instance, a low surviving fraction, deriving from a short-treatment time in low intensity is very susceptible to regrowth. The opposite statement, for higher light intensities and low temperatures to expect low regrowth, is validated as well. Special mention should be made at the nontreated samples (live fraction $=1$ ) that always present (re)growth. In contrast, in figure 8d, plotting the higher temperature experiments, we do not find live bacteria at $100 \%$, but we observe less regrowth after 24 (trace: $\square$ ) and 48h (trace: $\square$ ). Also, a higher number of experiments present near-zero regrowth, compared with the low-temperature experiments. Even samples that presented $90 \%$ live bacterial fraction present diminished numbers, with obvious positive effects of high temperature in suppressing regrowth. 
Finally, figure 9 presents an estimation of the bacteria transferred from the end of the treatment time to the first day and from these ones, in the second day. On $\mathrm{X}$ axis, we plot the final live fraction of bacteria after $24 \mathrm{~h}$, due to the bacteria at the end of treatment time $\mathrm{i}(\mathrm{i}=1-4 \mathrm{~h})$ per initial concentration and on $\mathrm{Y}$ axis the respective ones for $48 \mathrm{~h}$ storage. This ratio assesses the transferability of bacterial growth from day 1 to day 2 and expresses the fate at the end of the treatment time; i.e. values $>1$ indicate higher numbers after $48 \mathrm{~h}$, due to the live fraction in $24 \mathrm{~h}$. Mathematically, this ratio is $\frac{C_{24} / C_{0}}{C_{i} / C_{0}}$ or $\frac{C_{48} / C_{0}}{C_{i} / C_{0}}$, and is expressed as $\mathrm{C}_{24} / \mathrm{C}_{\mathrm{i}}$ or $\mathrm{C}_{48} / \mathrm{C}_{\mathrm{i}}$, respectively. As it seems, the transferability from day 1 to day 2 is strongly influenced by the treatment temperatures during the experiment; for low temperatures $20^{\circ} \mathrm{C} \leq \mathrm{T} \leq 40^{\circ} \mathrm{C}$, we observe that the same fraction of live bacteria after 1 day can yield higher fractions after $48 \mathrm{~h}$ (trace: $\bullet$ ) than the respective $40^{\circ} \mathrm{C}<\mathrm{T} \leq 60^{\circ} \mathrm{C}$ ones (trace: $\bullet$ ). For example, 24$\mathrm{h}$ ratios of 1 or 10 can result in much higher ratios (up to 1000) after $48 \mathrm{~h}$. It is shown that i) there is no repair on the damages inflicted by temperature and ii) the synergistic action of light and temperature ensures low transferability from the surviving fraction. The dominant trend existing in regrowth is also expressed by the logarithmic equations and the possibility of increased appearance after 2 days is reflected by the constants of the equations which describe that trend.

In overall, there is a lighter regrowth risk when high temperatures of treatment are applied. However, this condition is not always applicable, when it comes to the existing solar disinfection techniques. In that case, either higher light intensities must be accounted for, low (around $20^{\circ} \mathrm{C}$ ) ambient temperatures or maybe, prolongation of the exposure time can compensate the risk of remaining bacteria in the solution. In this manner, either light action will be enhanced, bacterial division will not be favored or extended damage will be inflicted, to ensure low live fractions at the end of the treatment; it was proved that this condition, regardless the pre-treatment condition, is a precursor of the bacterial numbers in short or long term storage of water.

\section{CONCLUSIONS}

- Non-irradiated samples of secondary effluent treated at $20-40^{\circ} \mathrm{C}$ showed slight growth during treatment, and high post-treatment regrowth (ratios of 250-1000). Significantly, thermal inactivation with no regrowth predominated at $50^{\circ} \mathrm{C}$ and was total at $60^{\circ} \mathrm{C}$.

- At $800 \mathrm{~W} / \mathrm{m}^{2}$, bacterial regrowth only occurred in incompletely disinfected samples, which are linked to lower irradiation, shorter times or high initial microorganism populations. No regrowth was observed in samples presenting no bacterial counts at the end of the treatment. An erratic behavior was observed when treatment temperature was among $20-40^{\circ} \mathrm{C}$, where prolongation of treatment resulted in higher long term re-appearance of bacteria in the samples, related to growth issues after $30^{\circ} \mathrm{C}$. 
- High intensities revealed almost no regrowth (special cases: 1-h treatment), for low temperatures, revealing the detrimental effect of elevated light intensities, whereas the combination of high temperatures with high intensity resulted in no regrowth and survival diminishing, as well, due to the very high levels of synergetic action between light and temperature.

446

447

448

- When present, regrowth was directly connected to the enumerated leftover bacteria. The lower temperature region promoted bacterial regrowth (max. in $30^{\circ} \mathrm{C}$ ) and high temperatures suppressed the reappearance, both in short and long term storage. Also, the lower temperature set demonstrated higher rate of transferring their live bacteria from the end of the treatment time towards the next days, than high temperatures.

- The temperature range for light-temperature synergy $\left(40-60^{\circ} \mathrm{C}\right)$ is well above the common temperatures in shallow ponds, even in tropical countries, while a normal sustained intensity lies around $800-900 \mathrm{~W} / \mathrm{m}^{2}$.

- $\quad$ Our study suggests that contact times longer than the $4 \mathrm{~h}$ observed here would be required at field conditions. Other field factors should be investigated, like shielding by particles (residual suspended solids, algae), for they would extend required exposure time to days.

\section{ACKNOWLEDGEMENTS}

The authors wish to thank, in order of acquisition, the Mediterranean Office for Youth Program (MOY, call 2011-2014), by means of which Mr. Stefanos Giannakis has received a PhD mobility grant (MOY grant No2010/044/01) in the joint Environmental Engineering Doctoral Program. Also would wish to thank the Swiss Government for the Swiss Government Excellence Scholarship, by means of which Mr. Stefanos Giannakis has received a Research Visit fellowship (No. 2012.0499).

\section{REFERENCES}

[1] C.D. Amsler, Algal chemical ecology, Springer, 2008.

[2] R.A. Blaustein, Y. Pachepsky, R.L. Hill, D.R. Shelton, G. Whelan, Escherichia coli survival in waters: Temperature dependence, Water research, 47 (2013) 569-578.

[3] M.A. Blesa, M.I. Litter, Low-cost TiO2 photocatalytic technology for water potabilization in plastic bottles for isolated regions. Photocatalyst fixation, (2007).

[4] A.B. Britt, DNA damage and repair in plants, Annual review of plant biology, 47 (1996) 75-100.

[5] Y. Chan, E. Killick, The effect of salinity, light and temperature in a disposal environment on the recovery of E. coli following exposure to ultraviolet radiation, Water research, 29 (1995) 1373-1377. 
[6] S.A. Craik, D. Weldon, G.R. Finch, J.R. Bolton, M. Belosevic, Inactivation of cryptosporidium parvum oocysts using medium-and low-pressure ultraviolet radiation, Water research, 35 (2001) 13871398.

[7] U. Fotadar, P. Zaveloff, L. Terracio, Growth of Escherichia coli at elevated temperatures, Journal of basic microbiology, 45 (2005) 403-404.

[8] J. Gamage, Z. Zhang, Applications of photocatalytic disinfection, International Journal of Photoenergy, 2010 (2010).

[9] S. Giannakis, E. Darakas, A. Escalas-Cañellas, C. Pulgarin, The antagonistic and synergistic effects of temperature during solar disinfection of synthetic secondary effluent, Journal of Photochemistry and Photobiology A: Chemistry, 280 (2014) 14-26.

[10] A.I. Gomes, J.C. Santos, V.J.P. Vilar, R.A.R. Boaventura, Inactivation of Bacteria E. coli and photodegradation of humic acids using natural sunlight, Applied Catalysis B: Environmental, 88 (2009) 283-291.

[11] M. Guo, J. Huang, H. Hu, W. Liu, Growth and repair potential of three species of bacteria in reclaimed wastewater after UV disinfection, Biomedical and Environmental Sciences, 24 (2011) 400407.

[12] C. Hallmich, R. Gehr, Effect of pre-and post-UV disinfection conditions on photoreactivation of fecal coliforms in wastewater effluents, Water research, 44 (2010) 2885-2893.

[13] W. Hijnen, E. Beerendonk, G.J. Medema, Inactivation credit of UV radiation for viruses, bacteria and protozoan (oo) cysts in water: a review, Water research, 40 (2006) 3-22.

[14] C. Jungfer, T. Schwartz, U. Obst, UV-induced dark repair mechanisms in bacteria associated with drinking water, Water research, 41 (2007) 188-196.

[15] C. Lage, P. Teixeira, A. Leitao, Non-coherent visible and infrared radiation increase survival to UV $(254 \mathrm{~nm})$ in Escherichia coli K12, Journal of Photochemistry and Photobiology B: Biology, 54 (2000) 155-161.

[16] K.G. Lindenauer, J.L. Darby, Ultraviolet disinfection of wastewater: effect of dose on subsequent photoreactivation, Water research, 28 (1994) 805-817.

[17] A. Martín-Domínguez, M.T. Alarcón-Herrera, I.R. Martín-Domínguez, A. González-Herrera, Efficiency in the disinfection of water for human consumption in rural communities using solar radiation, Solar Energy, 78 (2005) 31-40.

[18] J. Marugán, R. van Grieken, C. Pablos, C. Sordo, Analogies and differences between photocatalytic oxidation of chemicals and photocatalytic inactivation of microorganisms, Water research, 44 (2010) 789-796.

[19] S. Matallana-Surget, C. Villette, L. Intertaglia, F. Joux, M. Bourrain, P. Lebaron, Response to UVB radiation and oxidative stress of marine bacteria isolated from South Pacific Ocean and Mediterranean Sea, Journal of Photochemistry and Photobiology B: Biology, (2012).

[20] K. McGuigan, T. Joyce, R. Conroy, J. Gillespie, M. Elmore-Meegan, Solar disinfection of drinking water contained in transparent plastic bottles: characterizing the bacterial inactivation process, Journal of applied microbiology, 84 (1998) 1138-1148. 
[21] K.G. McGuigan, R.M. Conroy, H.J. Mosler, M. du Preez, E. Ubomba-Jaswa, P. FernandezIbanez, Solar water disinfection (SODIS): a review from bench-top to roof-top, Journal of hazardous materials, 235-236 (2012) 29-46.

[22] H.A. Munshi, N. Sasikumar, A. Jamaluddin, K. Mohammed, Evaluation of ultra-violet radiation disinfection on the bacterial growth in the swro pilot plant, Al-Jubail, in: Gulf Water Conference, 1999.

[23] E. Nebot Sanz, I. Salcedo Davila, J.A. Andrade Balao, J.M. Quiroga Alonso, Modelling of reactivation after UV disinfection: effect of UV-C dose on subsequent photoreactivation and dark repair, Water research, 41 (2007) 3141-3151.

[24] OECD Guidelines for Testing of Chemicals, Simulation Test-Aerobic Sewage Treatment 303A, 1999

[25] S. Pigeot-Rémy, F. Simonet, D. Atlan, J. Lazzaroni, C. Guillard, Bactericidal efficiency and mode of action: A comparative study of photochemistry and photocatalysis, Water research, 46 (2012) 32083218 .

[26] M.I. Polo-López, P. Fernández-Ibáñez, E. Ubomba-Jaswa, C. Navntoft, I. García-Fernández, P.S.M. Dunlop, M. Schmid, J.A. Byrne, K.G. McGuigan, Elimination of water pathogens with solar radiation using an automated sequential batch CPC reactor, Journal of hazardous materials, 196 (2011) 16-21.

[27] P.H. Quek, J. Hu, Indicators for photoreactivation and dark repair studies following ultraviolet disinfection, Journal of industrial microbiology \& biotechnology, 35 (2008) 533-541.

[28] R.H. Reed, The inactivation of microbes by sunlight: solar disinfection as a water treatment process, Advances in applied microbiology, 54 (2004) 333-365.

[29] J. Regensburger, A. Knak, A. Felgenträger, W. Bäumler, Generation of singlet oxygen by UVBirradiation of endogenous molecules, Photodiagnosis and Photodynamic Therapy, 8 (2011) 152.

[30] A.-G. Rincón, C. Pulgarin, Effect of pH, inorganic ions, organic matter and $\mathrm{H} 2 \mathrm{O} 2$ on E. coli K12 photocatalytic inactivation by $\mathrm{TiO} 2$ : Implications in solar water disinfection, Applied Catalysis B: Environmental, 51 (2004a) 283-302.

[31] A.-G. Rincón, C. Pulgarin, Bactericidal action of illuminated TiO2 on pure Escherichia coli and natural bacterial consortia: post-irradiation events in the dark and assessment of the effective disinfection time, Applied Catalysis B: Environmental, 49 (2004b) 99-112.

[32] A.-G. Rincón, C. Pulgarin, Field solar E. coli inactivation in the absence and presence of TiO2: is UV solar dose an appropriate parameter for standardization of water solar disinfection?, Solar Energy, 77 (2004c) 635-648.

[33] L. Rizzo, V. Belgiorno, R.M.A. Napoli, Regrowth Evaluation of Coliform Bacteria Injured by Low Chlorine Doses Using Selective and Nonselective Media, Journal of Environmental Science and Health, Part A, 39 (2004) 2081-2092.

[34] J. Rodríguez-Chueca, R. Mosteo, M.P. Ormad, J.L. Ovelleiro, Factorial experimental design applied to Escherichia coli disinfection by Fenton and photo-Fenton processes, Solar Energy, 86 (2012) 3260-3267.

[35] D. Roszak, R. Colwell, Survival strategies of bacteria in the natural environment, Microbiological reviews, 51 (1987) 365. 
[36] F. Sciacca, J.A. Rengifo-Herrera, J. Wéthé, C. Pulgarin, Solar disinfection of wild Salmonella sp.

557 in natural water with a 18L CPC photoreactor: Detrimental effect of non-sterile storage of treated 558 water, Solar Energy, 85 (2011) 1399-1408.

559 [37] C. Shang, L.M. Cheung, C.-M. Ho, M. Zeng, Repression of photoreactivation and dark repair of 560 coliform bacteria by TiO2-modified UV-C disinfection, Applied Catalysis B: Environmental, 89 561 (2009) 536-542.

562 [38] R.P. Sinha, D.-P. Häder, UV-induced DNA damage and repair: a review, Photochemical \& 563 Photobiological Sciences, 1 (2002) 225-236.

564 [39] D. Spuhler, J. Andrés Rengifo-Herrera, C. Pulgarin, The effect of Fe2+, Fe3+, H2O2 and the 565 photo-Fenton reagent at near neutral $\mathrm{pH}$ on the solar disinfection (SODIS) at low temperatures of 566 water containing Escherichia coli K12, Applied Catalysis B: Environmental, 96 (2010) 126-141.

567 [40] E. Ubomba-Jaswa, C. Navntoft, M.I. Polo-Lopez, P. Fernandez-Ibanez, K.G. McGuigan, Solar 568 disinfection of drinking water (SODIS): an investigation of the effect of UV-A dose on inactivation 569 efficiency, Photochemical \& Photobiological Sciences, 8 (2009) 587-595.

570 [41] G.C. White, White's handbook of chlorination and alternative disinfectants, Wiley, 2010.

571 [42] H.-S. Xu, N. Roberts, F.L. Singleton, R.W. Attwell, D.J. Grimes, R.R. Colwell, Survival and 572 Viability of Nonculturable Escherichia coli and Vibrio cholerae in the Estuarine and Marine 573 Environment, Microbial ecology, 8 (1982) 313-323. 


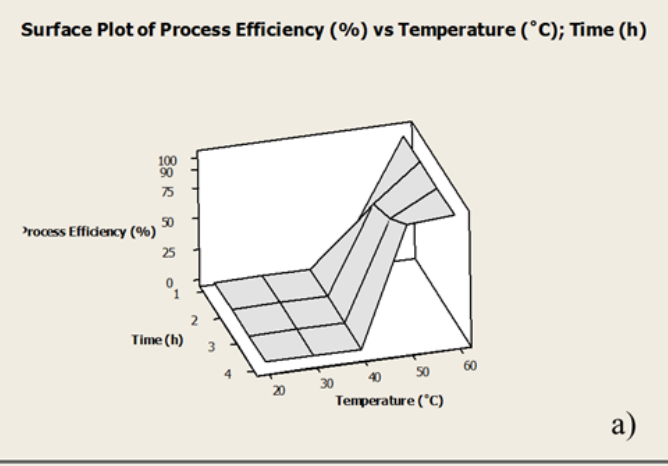

Surface Plot of Process Efficiency (\%) vs Temperature ( $\left.{ }^{\circ} \mathrm{C}\right)$; Time ( $(\mathrm{h})$

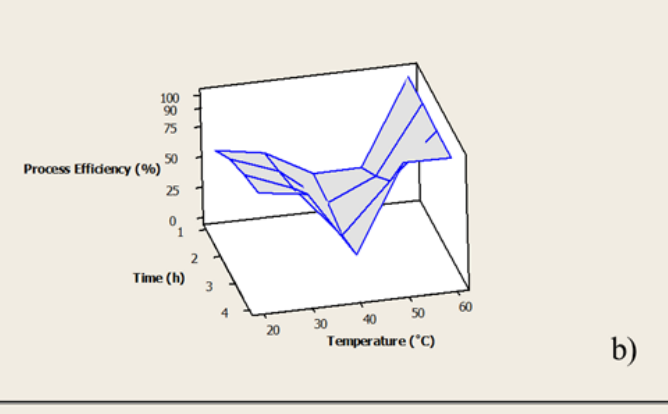

Surface Plot of Process Efficiency (\%) vs Temperature ( $\left.{ }^{\circ} \mathrm{C}\right)$; Time ( $h$ )

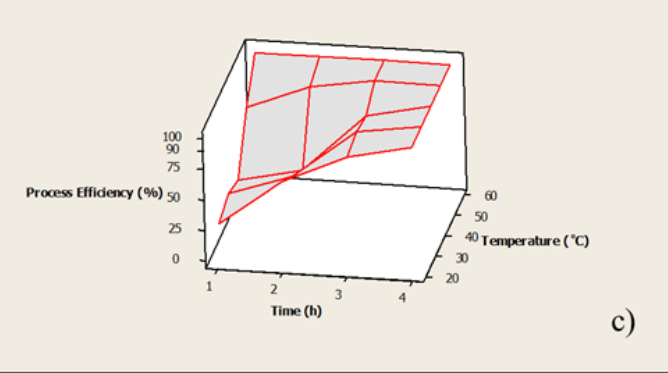

Figure 1 - Overview of disinfection experiments. Process efficiency vs. treatment time and temperature is plotted. a) $\left.0 \mathrm{~W} / \mathrm{m}^{2} . b\right) 800 \mathrm{~W} / \mathrm{m}^{2}$. c) $1200 \mathrm{~W} / \mathrm{m} 2$ 


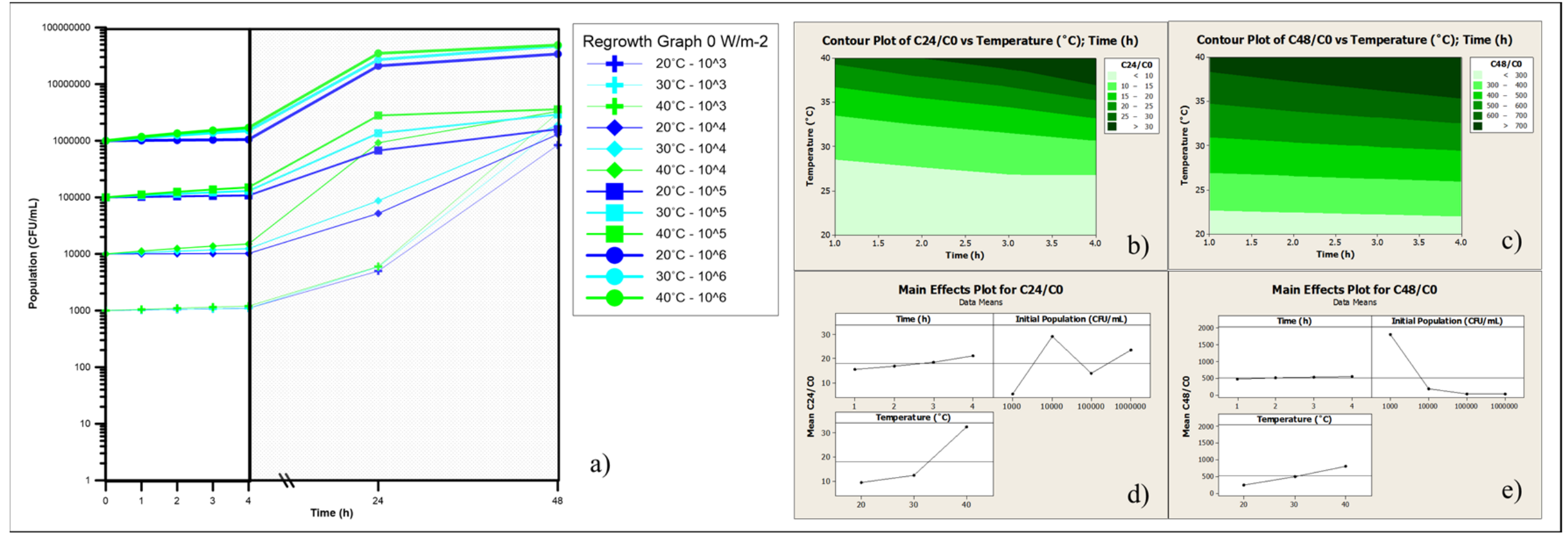

Figure 2 - Main results of non-irradiation experiments for synthetic secondary effluent at among $20-40^{\circ} \mathrm{C}$ and all initial E. coli populations. (a) Post-treatment regrowth curves. (b) Contour plot of regrowth after 1 day vs. temperature and time. (c) Contour plot of regrowth after 2 days vs. temperature and time. (d) Main effects plot (control variable: Regrowth after 1 day). (e) Main effects plot (control variable: Regrowth after 2 days). 


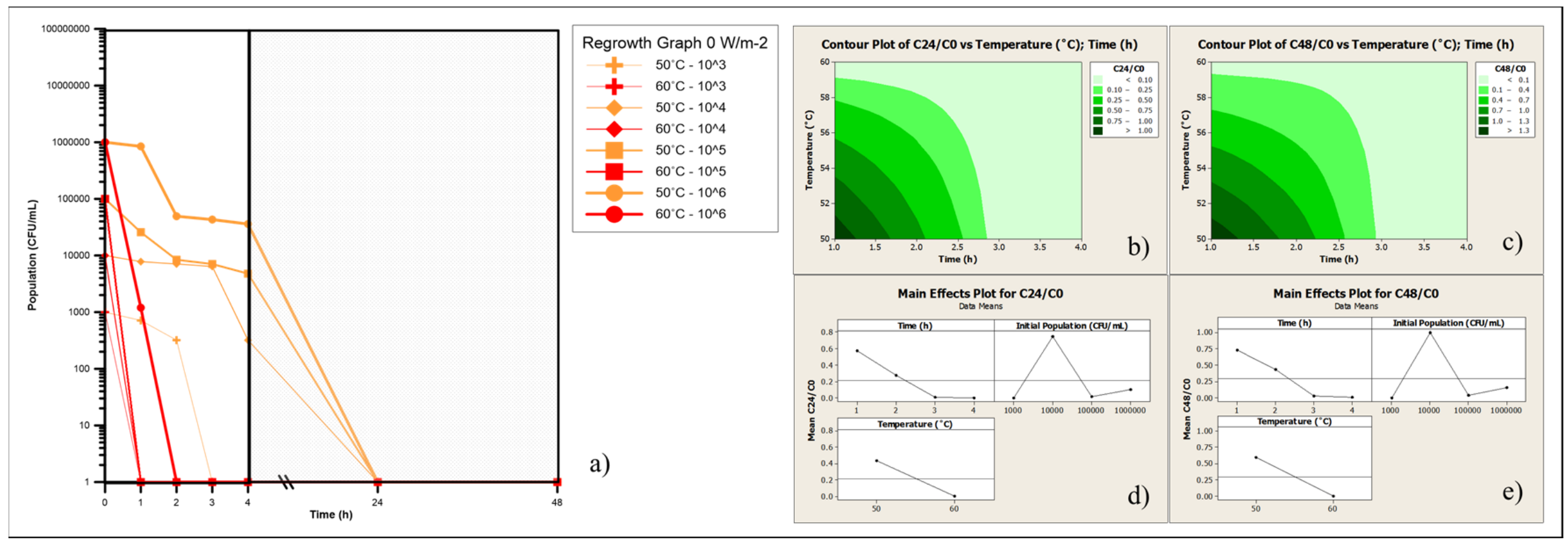

Figure 3 - Main results of non-irradiation experiments for synthetic secondary effluent at among $50-60^{\circ} \mathrm{C}$ and all initial E. coli populations. (a) Post-treatment regrowth curves. (b) Contour plot of regrowth after 1 day vs. temperature and time. (c) Contour plot of regrowth after 2 days vs. temperature and time. (d) Main effects plot (control variable: Regrowth after 1 day). (e) Main effects plot (control variable: Regrowth after 2 days). 


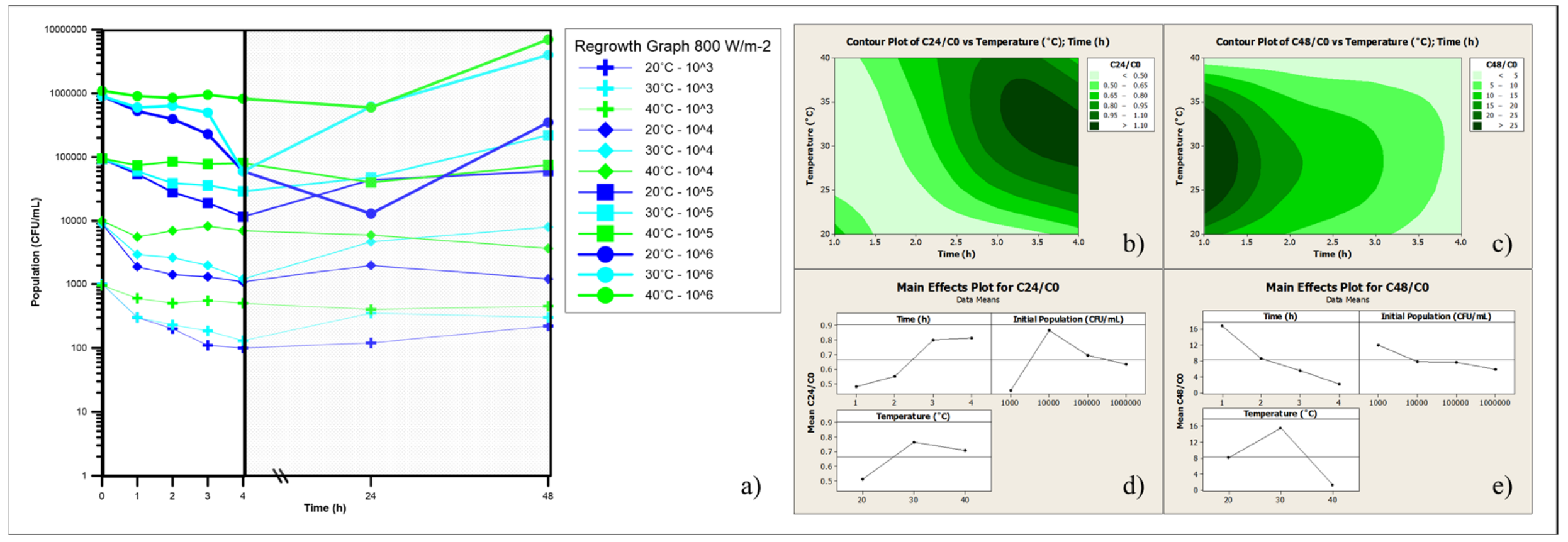

Figure 4 - Main results of $800 \mathrm{~W} / \mathrm{m}^{2}$-irradiated experiments for synthetic secondary effluent at among $20-40^{\circ} \mathrm{C}$ and all initial E. coli populations. (a) Posttreatment regrowth curves. (b) Contour plot of regrowth after 1 day vs. temperature and time. (c) Contour plot of regrowth after 2 days vs. temperature and time. (d) Main effects plot (control variable: Regrowth after 1 day). (e) Main effects plot (control variable: Regrowth after 2 days). 


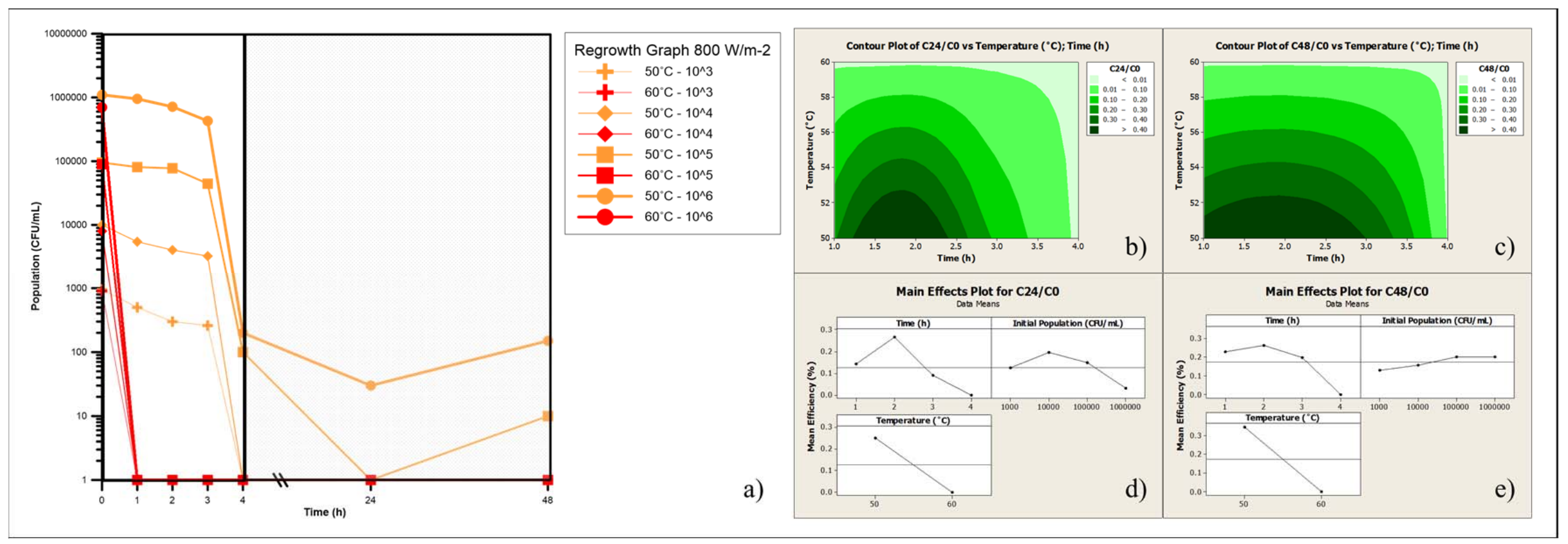

Figure 5 - Main results of $800 \mathrm{~W} / \mathrm{m}^{2}$-irradiated experiments for synthetic secondary effluent at among $50-60^{\circ} \mathrm{C}$ and all initial E. coli populations. (a) Posttreatment regrowth curves. (b) Contour plot of regrowth after 1 day vs. temperature and time. (c) Contour plot of regrowth after 2 days vs. temperature and time. (d) Main effects plot (control variable: Regrowth after 1 day). (e) Main effects plot (control variable: Regrowth after 2 days). 


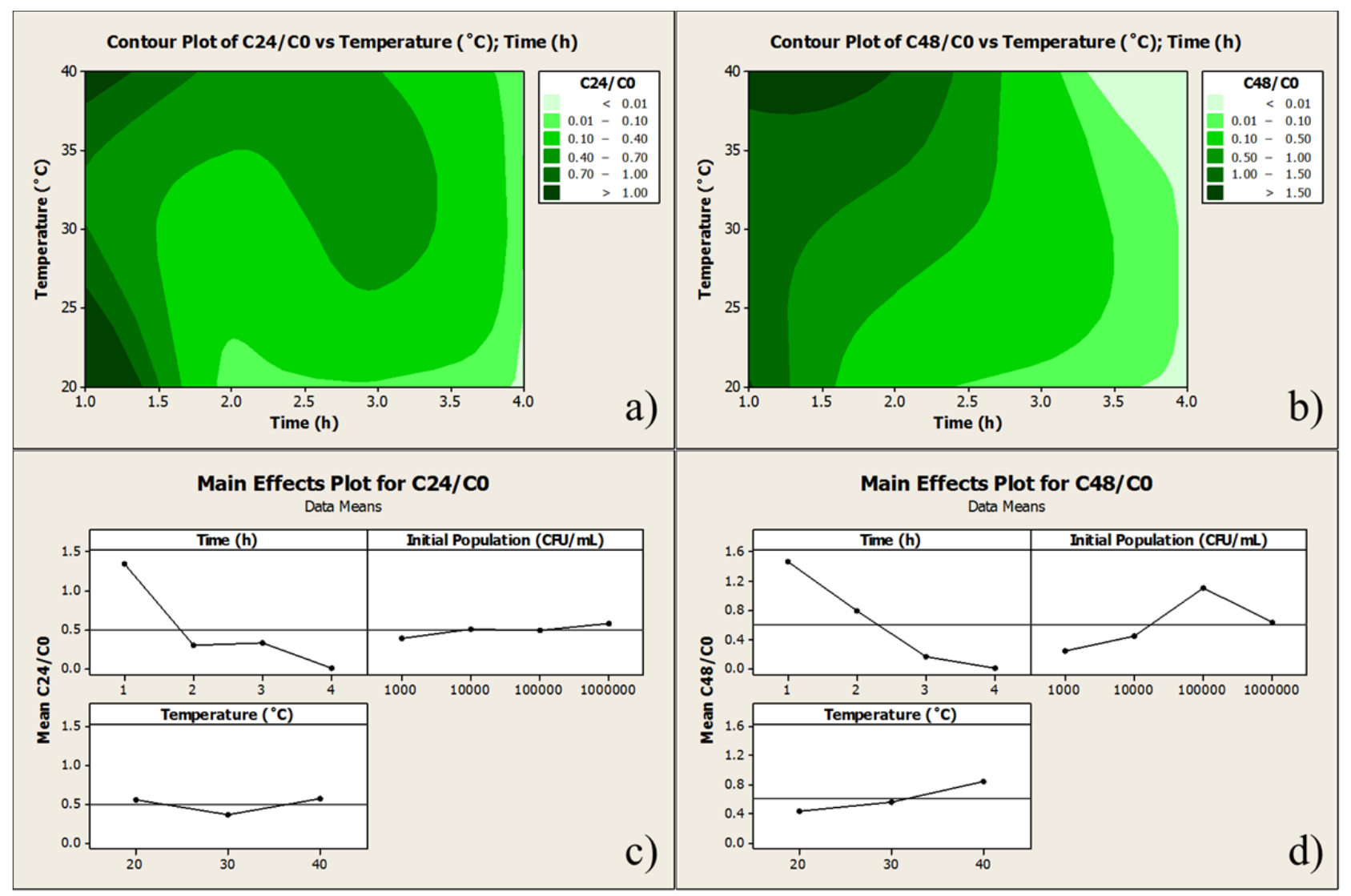

Figure 6 - Overview of the $1200 \mathrm{~W} / \mathrm{m}^{2}$-irradiation experiments, among $20-40^{\circ} \mathrm{C}$ and all initial $\mathrm{E}$. coli populations. (a) Contour plot of regrowth after 1 day vs. temperature and time. (b) Contour plot of regrowth after 2 days vs. temperature and time. (c) Main effects plot (control variable: Regrowth after 1 day). (d) Main effects plot (control variable: Regrowth after 2 days). 


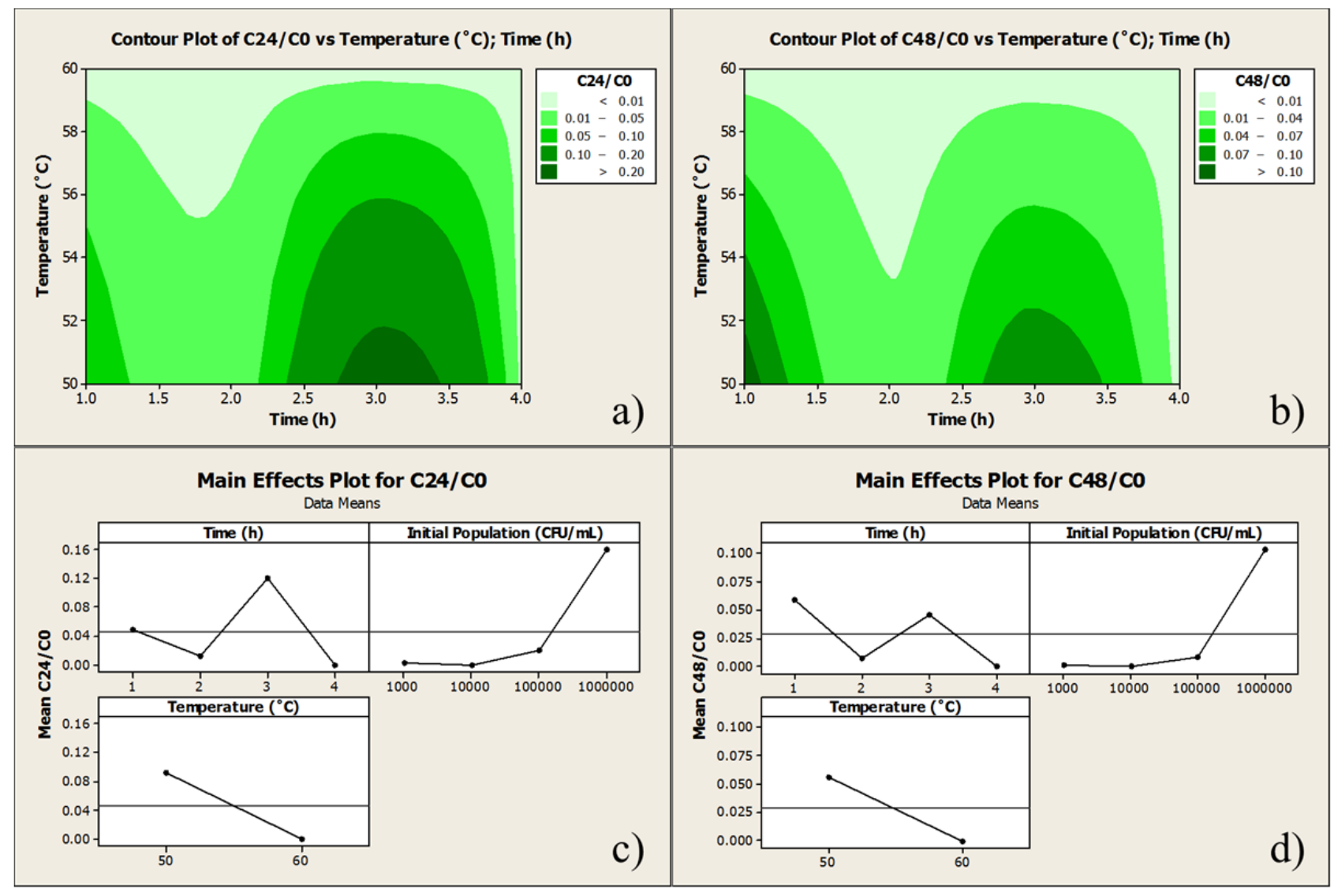

Figure 7 - Overview of the $1200 \mathrm{~W} / \mathrm{m}^{2}$-irradiation experiments, among $50-60^{\circ} \mathrm{C}$ and all initial E. coli populations. (a) Contour plot of regrowth after 1 day vs. temperature and time. (b) Contour plot of regrowth after 2 days vs. temperature and time. (c) Main effects plot (control variable: Regrowth after 1 day). (d) Main effects plot (control variable: Regrowth after 2 days). 


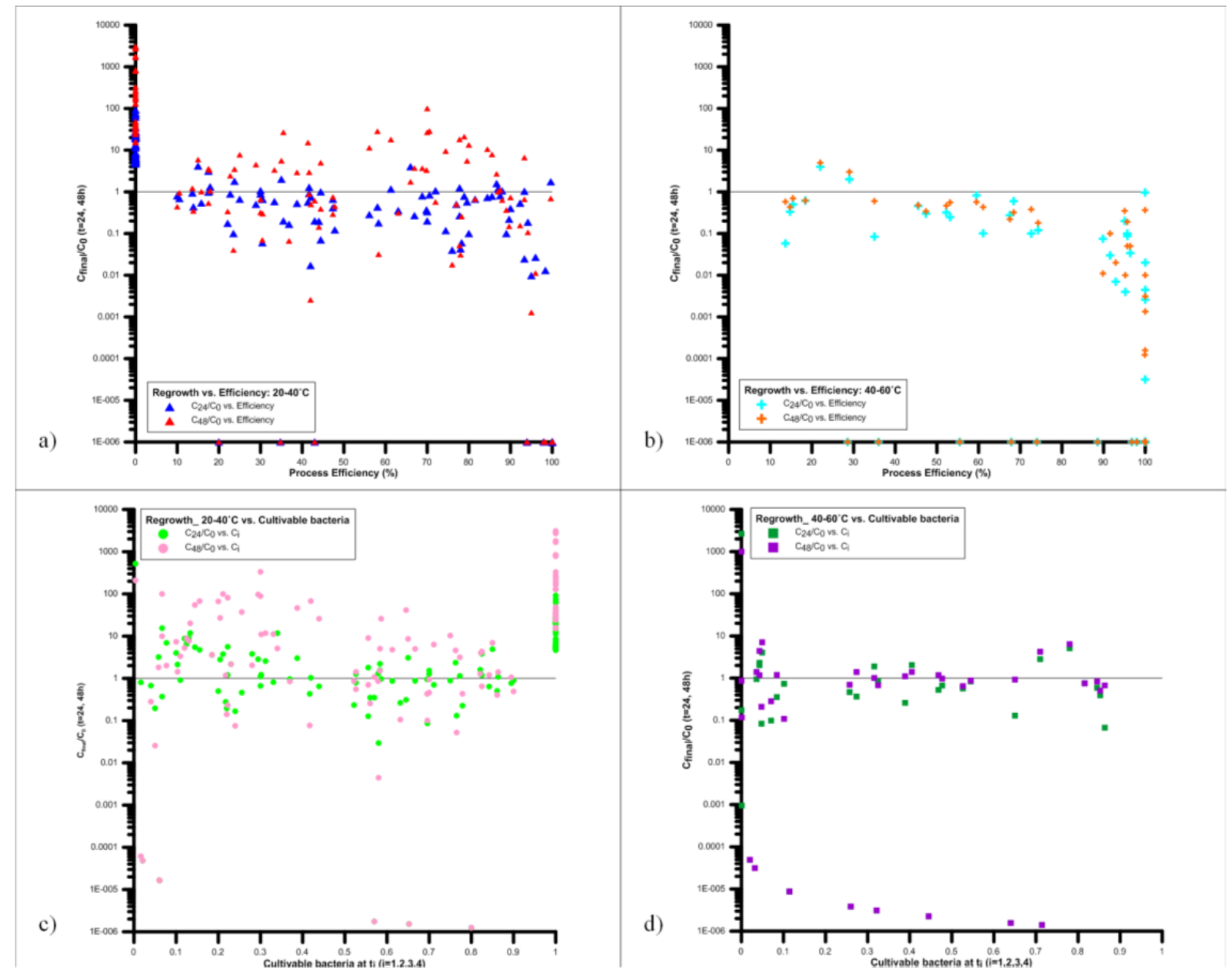

Figure 8 - Statistical interpretation of regrowth vs. disinfection efficiency. (a) Efficiency vs. Regrowth after 1 day. (b) Efficiency vs. Regrowth after 2 days. (c) Live fraction at the end of the treatment period (1-4 h) vs. Regrowth after 1 day. (d) Live fraction at the end of the treatment period (1-4 h) vs. Regrowth after 2 days. 


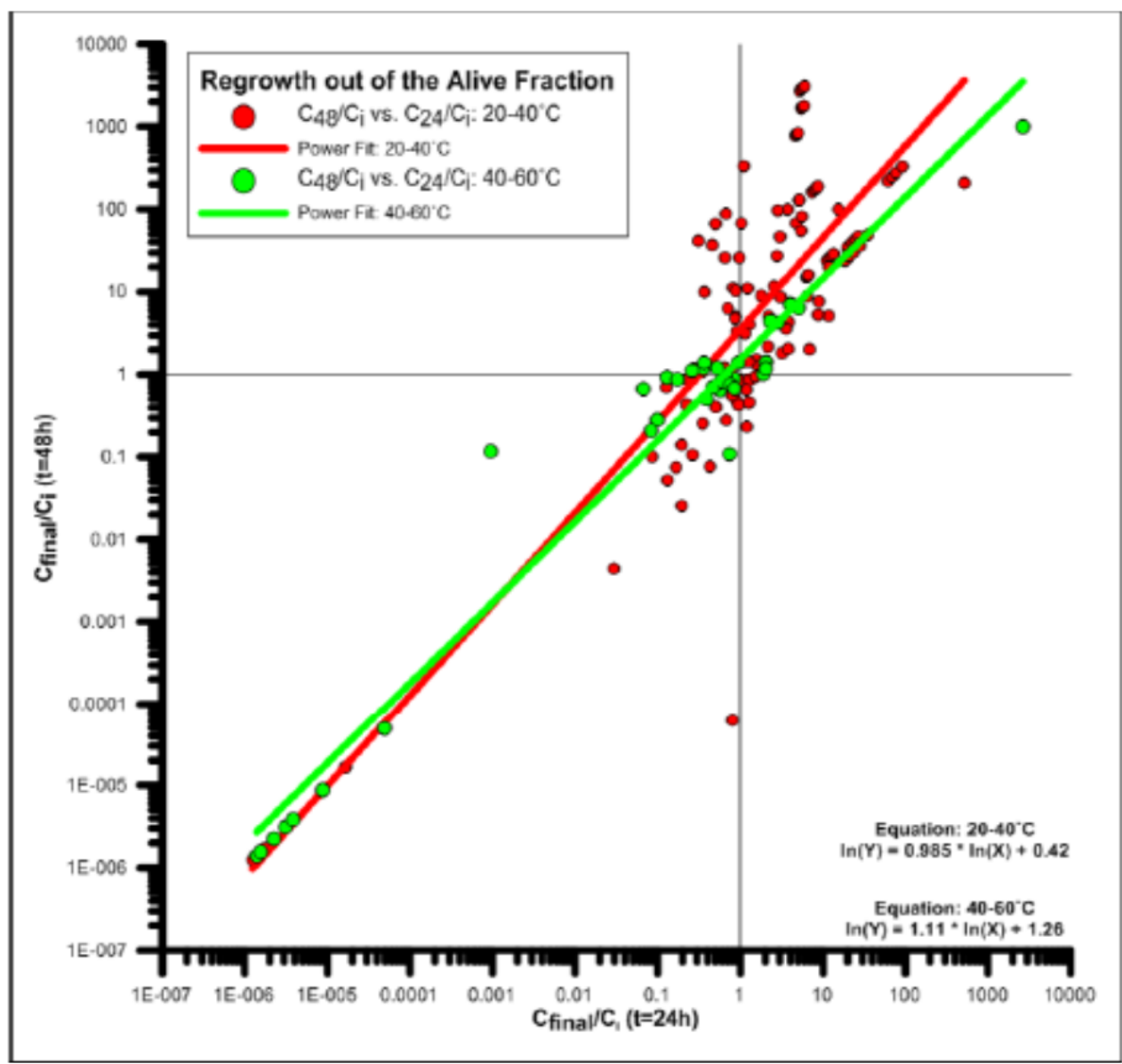

Figure 9 - Transferability of live bacteria through the post-irradiation treatment period. Regrowth after $24 \mathrm{~h}$ out of the live fraction subjected to $\mathrm{i}$ hours of treatment (i=1-4 h) vs. Regrowth after $48 \mathrm{~h}$. 
Table 1 - Synthetic wastewater composition

Chemical composition of the synthetic municipal wastewater before dilution

Chemicals Concentration (mg/L)

\begin{tabular}{c|c} 
Peptone & 160 \\
Meat extract & 110 \\
Urea & 30 \\
$\mathrm{~K}_{2} \mathrm{HPO}_{4}$ & 28 \\
$\mathrm{NaCl}$ & 7 \\
$\mathrm{CaCl}_{2} \cdot 2 \mathrm{H}_{2} \mathrm{O}$ & 4 \\
$\mathrm{Mg}_{2} \mathrm{SO}_{4} \cdot 7 \mathrm{H}_{2} \mathrm{O}$ & 2
\end{tabular}


Table 2 - Disinfection conditions employed in the DOE.

\begin{tabular}{c|c} 
Parameters & Levels \\
\hline Time $(\boldsymbol{h})$ & $1,2,3,4$ \\
Initial Population $(\boldsymbol{C F U} / \mathbf{m L})$ & $10^{3}, 10^{4}, 10^{5}, 10^{6}$ \\
Temperature $\left({ }^{\circ} \mathrm{C}\right)$ & $20,30,40,50,60$ \\
Light Intensity $\left(\mathrm{W} / \mathrm{m}^{2}\right)$ & $0,800,1200$
\end{tabular}


Table 3 - Inactivation efficiency $\%$ after $4 \mathrm{~h}$ (at the end of each treatment method) for 0,800 and $1200 \mathrm{~W} / \mathrm{m}^{2}$.

\begin{tabular}{|c|c|c|c|c|c|}
\hline Intensity & Population (CFU/mL) / Temperature $\left({ }^{\circ} \mathrm{C}\right)$ & $10^{3}$ & $10^{4}$ & $10^{5}$ & $10^{6}$ \\
\hline \multirow{5}{*}{$\frac{1}{3}$} & $20^{\circ} \mathrm{C}$ (\% growth) & 10 & 2 & 8 & 5 \\
\hline & $30^{\circ} \mathrm{C}$ (\% growth) & 10 & 24 & 30 & 50 \\
\hline & $40^{\circ} \mathrm{C}$ (\% growth) & 20 & 50 & 50 & 70 \\
\hline & $50^{\circ} \mathrm{C}$ & 100 & 96.8 & 95.2 & 95 \\
\hline & $60^{\circ} \mathrm{C}$ & 100 & 100 & 100 & 100 \\
\hline \multirow{5}{*}{$\frac{\sqrt{\Sigma}}{3}$} & $20^{\circ} \mathrm{C}$ & 90 & 88 & 87.5 & 93.3 \\
\hline & $30^{\circ} \mathrm{C}$ & 87 & 86.7 & 68.8 & 93.3 \\
\hline & $40^{\circ} \mathrm{C}$ & 47.4 & 30 & 15.8 & 25 \\
\hline & $50^{\circ} \mathrm{C}$ & 100 & 100 & 99.9 & 99.9 \\
\hline & $60^{\circ} \mathrm{C}$ & 100 & 100 & 100 & 100 \\
\hline \multirow{5}{*}{ 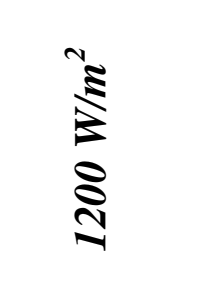 } & $20^{\circ} \mathrm{C}$ & 100 & 100 & 100 & 100 \\
\hline & $30^{\circ} \mathrm{C}$ & 100 & 100 & 100 & 100 \\
\hline & $40^{\circ} \mathrm{C}$ & 100 & 100 & 100 & 100 \\
\hline & $50^{\circ} \mathrm{C}$ & 100 & 100 & 100 & 100 \\
\hline & $60^{\circ} \mathrm{C}$ & 100 & 100 & 100 & 100 \\
\hline
\end{tabular}

